\title{
Intención Emprendedora Académica: un estudio a través de la Teoría del Comportamiento Planeado
}

Academic Entrepreneurial Intention: a study through the Theory of Planned Behavior

\author{
Beatriz M. Terán-Pérez ${ }^{1}$ (D) https://orcid.org/0000-0002-7561-9938 \\ Cuitláhuac Valdez-Lafarga ${ }^{1}$ (I) https://orcid.org/0000-0001-7876-1430 \\ Alejandra Miranda-Félix ${ }^{2}$ (D) https://orcid.org/0000-0001-5469-0834 \\ Pedro Flores-Leal ${ }^{1}$ (D) https://orcid.org/0000-0002-1007-8763 \\ ${ }^{1}$ Universidad Autónoma de Occidente, ${ }^{\square}$ bemaita13@gmail.com \\ ${ }^{2}$ Universidad Autónoma de Sinaloa \\ (C) Universidad De La Salle Bajío (México)
}

Recibido en: 26 - 10 - 2020 / Aceptado en: $02-04-2021$

\section{Resumen}

Introducción: El estudio de la intención emprendedora es primordial para entender el inicio del proceso de emprendimiento. La literatura en emprendimiento académico sustenta que existe escasez de investigaciones relacionadas con el cómo un individuo, en el entorno académico, desarrolla la intención de emprender un spin-off. Partiendo de la Teoría del Comportamiento Planeado, el objetivo del presente estudio es analizar la incidencia de los antecedentes motivacionales (actitud, norma subjetiva y control percibido) en la Intención Emprendedora Académica y examinar el efecto de los factores individuales (creatividad, utilidad percibida, autoconfianza, experiencia empresarial) y del contexto (experiencia empresarial, capacitación en emprendimiento y entorno de negocios) en dichos antecedentes.

Método: La recolección de datos fue a través de una encuesta aplicada de forma aleatoria a 172 académicos de la Universidad Autónoma de Sinaloa en diversas áreas del conocimiento (técnicas y sociales). El análisis de datos se llevó a cabo mediante la técnica multivariante Modelo de Ecuaciones Estructurales, a través del enfoque de Mínimos Cuadrados Parciales, para ello se utilizó el software Smart PLS.

Resultados: El resultado del modelo de ecuaciones estructurales evidenció que el antecedente principal de la intención emprendedora académica es la Actitud hacia el emprendimiento. Esta, a su vez, se ve influida por la Creatividad y la Utilidad Percibida.

Discusión o Conclusión: El modelo estructural de la investigación permite proporcionar evidencia predictiva de variables no observables que inciden en la formación de la intención emprendedora 
en el entorno académico. Además, los hallazgos presentan implicaciones prácticas que son de utilidad a la gestión universitaria para el impulso al emprendimiento académico.

Palabras clave: emprendimiento académico; spin-off académico; intención emprendedora; teoría del comportamiento planeado; universidad; educación; entorno académico; emprendimiento; investigación; creatividad; experiencia empresarial

\begin{abstract}
Introduction: The study of Entrepreneurial Intention is essential to understand the beginning of the entrepreneurship process. The literature on academic entrepreneurship sustains a shortage of research related to how an individual, in the academic environment, develops the entrepreneurial intention of starting a spin-off. Starting from the Theory of Planned Behavior, the objective of the present study is to analyze the incidence of motivational antecedents (attitude, subjective norm, and perceived control) on Academic Entrepreneurial Intention and examine the effect of individual factors (creativity, perceived utility, self-confidence, business experience) and context (business experience, entrepreneurship training, and business environment) in said antecedents.

Method: The data collection was through a survey applied randomly to 172 academics from the Universidad Autónoma de Sinaloa in various areas of knowledge (technical and social). Data analysis was carried out using the multivariate Structural Equation Model technique, through the Partial Least Squares approach, for which the Smart PLS software was used.

Results: The result of the structural equation model showed that the main antecedent of the academic entrepreneurial intention is the attitude towards entrepreneurship. This, in turn, is influenced by Creativity and Perceived Utility.
\end{abstract}

Discussion or Conclusion: The research's structural model allows predictive evidence of unobservable variables that influence entrepreneurial intention's formation in the academic environment. Also, the findings present practical implications that are useful for university authorities to promote academic entrepreneurship.

Keywords: academic entrepreneurship; academic spin-off; entrepreneurial intention; theory of planned behavior; university; education; academic environment; entrepreneurship; research; creativity; business experience 


\section{Introduction}

From a critical perspective of the literature on academic entrepreneurship, it sustains that the role of the scientist, academic, or researcher in the entrepreneurial process is neglected (Etzkowitz et al., 2000; Goethner et al., 2012; Perkmann et al., 2013; Urban and Chantson, 2017; Wang et al., 2021; Wright, 2014), there is a shortage of studies related to how an individual involved in the academic environment identifies the business opportunity and develops the entrepreneurial intention of starting a spin-off based on the results of their research (Guerrero et al., 2016; Miranda et al., 2018; Prodan and Drnovsek, 2010; Rasmussen and Wright, 2015).

In this sense, previous contributions show that the study of entrepreneurial intention (EI) is essential to understand the entrepreneurship process (Kautonen et al., 2015; Kolvereid, 2016). The closest predictor of the decision to become an entrepreneur is seen in EI; the intention can foreshadow behaviors (Fini et al., 2012), indicates how intensely you prepare and how much effort you are planning to commit to carrying out an entrepreneurial behavior (Bird, 1988; Carsrud and Brannback, 2011).

According to Theory of Planned Behavior (TPB), human behavior is planned and is preceded by the intention towards that behavior. Also, TPB maintains that EI is influenced by motivational factors that include beliefs about an outcome; these factors' importance in predicting intention varies according to behaviors, situations, and population (Ajzen, 1991).

Thus, previous research has considered the TPB model as a theoretical framework, confirming the concept's application in different settings (Entrialgo and Iglesias, 2016; Liñan and Fayolle, 2015). However, specifically in the academic field, it is evident that most of the literary production related to empirical studies in which EI models are developed has been in students and, to a lesser extent, in university academics (Al-Jubari et al., 2018; Feola et al., 2017; Miranda et al., 2017; Obschonka et al., 2015).

Consequently, starting from the TPB, this study aims to analyze the incidence of motivational antecedents (Attitude, Subjective Norm, and Perceived Control) on Academic Entrepreneurial Intention (AEI) and examine the effect of individual factors and context on the antecedents of the AEI.

This article is structured as follows: the first section presents a review of the literature on TPB's motivational antecedents and the individual factors and the context that have been considered in studies of academic entrepreneurship with a theoretical foundation in EI. The second 
section refers to the methodology used for data collection and analysis. Later, in section three, the study results, conclusions, and implications are discussed.

\section{Literature Review}

\section{Theory of Planned Behavior}

From a cognitive approach, the best element to predict deliberate and planned behavior is the intention, mainly when said behavior is complex, difficult to observe, or involves an unpredictable period (Ajzen and Fishbein, 1980). TPB postulates that intention predicts human behavior, where intention indicates the extent of the effort of a person who plans to perform that behavior (Ajzen, 1991). In other words, when a person decides or not to take action, they tend to have prior planning, which is to say they have an intention (Ajzen, 2002). Explaining and predicting human behavior is the central purpose of TPB development, this theory comes from the field of psychology and has had satisfactory applications in others knowledge areas such as marketing and management (AlMamary et al., 2020) or career choice (Deprez et al., 2019).

Particularly, TPB represents a framework for the study of entrepreneurship, where it is considered superior and more influential than other models of intention (Al-Jubari et al., 2018; Entrialgo and Iglesias, 2016; Liñán and Fayolle, 2015), such as the business event model (Shapero and Sokol 1982) and the entrepreneurial potential model (Krueger and Brazeal 1994). TPB allows addressing the analysis of the intentions of the entrepreneurs, conditioned by the result they hope to obtain, the perceptions of the environment and the perception that the entrepreneur has of their ability to control and achieve the results of their entrepreneurial action (Liñan and Chen, 2009; Van Gelderen et al., 2008; Wang et al., 2020).

According to Ajzen's TPB (1991), the intention that precedes a behavior is determined by three motivational factors: 1) Attitude towards the behavior, 2) Subjective Norm, and 3) Perceived Control of the behavior. Collectively, these factors represent people's actual Control over behavior and may be preceded by the beliefs of each individual (Ajzen, 1991; Ajzen, 2011). Previous studies in entrepreneurship found that these three antecedents of the TPB explain 30-45\% of the variation of intentions (Liñan and Chen, 2009). 


\section{Attitude}

Attitude towards behavior refers to people's general evaluation to carry out a particular behavior; it can be positive or negative, weak, or strong, and explicit or implicit (Ajzen, 1991). A positive or favorable attitude towards a behavior, such as starting a business, is formed when perceived to have beneficial and desirable consequences. Specifically, the attitude towards entrepreneurship (AE) has shown a consistent and significant impact on EI in most of the research carried out in various contexts (Al-Jubari et al., 2018; Kautonen et al., 2015; Kolvereid, 2016). Considering the above, the following working hypothesis is proposed.

H1. AE significantly influences AEI.

\section{Subjective Norm}

The Subjective Norm (SN) refers to the individual's perception of how the people in their life perceive their participation or not in a particular behavior, such as starting a business. That is, SN considers the perceived support of other people -family, friends, work colleagues- valued by the individual's own motivation to fulfill the aspirations of these people (Kautonen et al., 2013). In previous studies, the effect of SN on Entrepreneurial Intent has varied substantially; in general, it has been found that SN is the weakest predictor of EI (Krueger et al., 2000; Liñán and Chen, 2009), but instead of excluding SN from TPB, some authors have chosen to study the effects of SN on Attitude towards Entrepreneurship and Perceived Control (Liñan et al., 2011; Lortie and Castogiovanni, 2015; Urban and Chantson, 2017). Therefore, the following hypothesis is stated:

H2: SN significantly influences AEI.

H2a: SN significantly influences AE.

H2b: SN significantly influences PC.

\section{Perceived Control of Behavior}

Perceived Control (PC) refers to the ability perceived by the individual to perform some behavior; it relates to the resources and opportunities available to a person, which to some degree, should dictate the probability of achievement in behavior (Ajzen, 1991). According to TPB, perceived control influences behavior directly or indirectly through intention. Various studies have found that PC is positively related to entrepreneurial intention, specifically in the academic environment; it allows overcoming the perception of financial and technological uncertainty (Feola et al., 2017; 
Fernández Pérez et al., 2015; Obschonka et al., 2015). Therefore, the following research hypothesis is proposed:

H3: PC significantly influences AEI.

\section{Individual and Context Factors as Precedents of TPB}

The literature emphasizes that academic entrepreneurial intention is a multilevel phenomenon, determined by contextual and individual factors. Specifically, articles have been published based on some intention models, and they also consider different antecedents that determine the AEI. Thus, for example, about individual characteristics and AEI, some studies consider scientific production (Goel et al., 2015; Prodan and Drnovsek, 2010) and creativity (Jain et al., 2009; Miranda et al., 2017; Zampetakis et al., 2009) as factors that determine the attitude towards entrepreneurship. Regarding context factors, the academic researcher's experience in the productive sector (Erikson et al., 2015; Moog et al., 2015; Miranda et al., 2017; Prodan and Drnovsek, 2010), the family environment (Foo et al., 2016), social and business networks (Fernández-Pérez et al., 2015), the triple helix (Feola et al., 2017), institutional and organizational barriers (Erikson et al., 2015; Guerrero and Urbano, 2014; Huyghe and Knockaert, 2015; Urban and Chantson, 2017) significantly affect the AEI.

Starting from the TPB and according to the gaps opened by previous studies, to continue analyzing the EI through a combination of the academics' individual factors and the region's contextual factors (Foo et al., 2016; Miranda et al., 2017), the research model used in the present study is shown in Fig. 1, the TPB is extended considering four antecedents predictors of the AE construct: Creativity (CREA), perceived utility (UP), self-confidence (SELF), and business experience (BE), as well as three antecedents of the PC: business experience (BE), entrepreneurship training (ET) and business environment (ENV). 


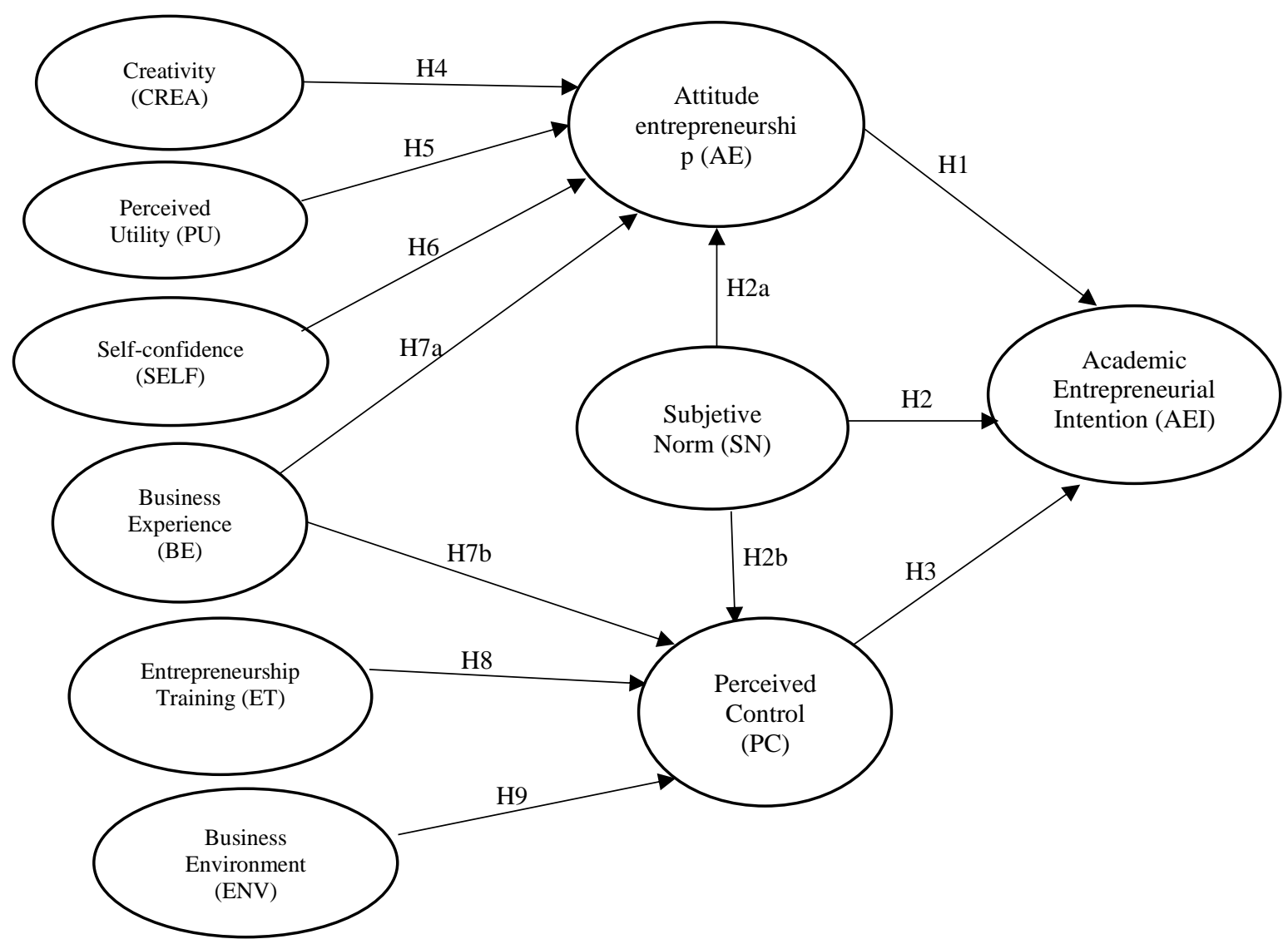

Fig. 1. Research Model.

Creativity (CREA). It is an important component of individual cognitive processing, can be defined as a personality trait that implies a willingness to pursue decisions or courses of action in a new way, even when it entails uncertainty regarding the results of success or failure (Batool $e t$ al., 2015). In the field of entrepreneurship, CREA at an individual level refers to the key element at the beginning of the entrepreneurial process in which entrepreneurs can combine existing resources, generate new ideas to start innovative businesses (Hu et al., 2018) or exploitation of business opportunities (Zampetakis et al., 2011), that is to say, they have the ability of matching information and knowledge to create new and valuable ideas (Shahab et al., 2018; Zhang and Zhang, 2018). The results of several studies are not conclusive on CREA and EI in the academic context. Shi et al. (2020) sustain that people with high CREA can maintain a positive attitude and high self-confidence in entrepreneurial activities, and Miranda et al. (2017) argue that there is no direct relationship between CREA and intention and propose an indirect connection through AE. Therefore, we posit the following hypothesis:

H4: CREA significantly influences AE. 
Perceived Utility (PU). According to Miranda et al. (2017), previous studies related to entrepreneurship have offered models of expected utility to describe the factors that influence an individual's choice to pursue a business career. The perception of economic benefits and the amount of work effort anticipated to achieve them are important factors when deciding to become an entrepreneur ( $\mathrm{Wu}$ and $\mathrm{Li}, 2011$ ). Against this background, the following hypothesis is:

H5: PU significantly influences AE.

Self-confidence (SELF). According to Ferreira et al. (2012), self-confidence (SELF) is identified as one of the main antecedents of AE. Margahana (2019) argues that self-confidence allows convincing others and improves individual motivation to achieve established goals. Specifically, in the academic field, Miranda et al. (2017) suggests a direct relationship between SELF and the attitude towards entrepreneurship. Consequently, the following hypothesis is:

H6: SELF significantly influences AE.

Business experience (BE). Several prior studies emphasized individual attributes, acquired from education and industrial experience, are the most significant determinants in promoting academic entrepreneurship activities (Wang et al., 2020; Wang et al., 2021). Academics with less experience in the industry find it difficult to identify opportunities for commercialization of their research results (Perkmann et al., 2013). In contrast, individuals who have had previous contact, through their family or professionally, in the business sector have a positive perception of carrying out entrepreneurial initiatives (D'Este and Perkmann, 2011; Prodan and Drnovsek, 2010). Miranda et al. (2017) argues that the previous experience of academics with the business sector through patents, collaborative research projects/contracts, and networks have a direct influence on their Attitude towards entrepreneurship (AE) and Perceived Control (PC). Therefore, we posit the following hypothesis:

H7a: Academic BE significantly influences AE.

H7b: Academic BE significantly influences PC.

Entrepreneurship Training (ET). Training and contact with entities that provide support to entrepreneurs tend to favor the willingness to start a business (Miranda et al., 2017). Previous studies show that the ET directly affects the PC because it allows access to entrepreneurs' resources 
and networks (Rauch and Hulsink, 2015). For their part, Rasmussen, and Wright (2015) acknowledge that many academics lack the necessary skills to start a business since those skills are very different from those they use in their academic life. There is little evidence of ET's impact on the likelihood that academics will engage in entrepreneurship (Miranda et al., 2017). Against this background, the following research hypothesis is proposed:

H8: The academic's ET significantly influences PC.

Business Environment (ENV). Various studies emphasize the importance of government policies to support business activities in the region (incubators, science parks, economic incentives, among others) and, particularly, government support mechanisms to encourage university academic entrepreneurship, for example, seed capital for the spin-off (Davey et al., 2016; Fini and Toschi, 2015; Foo et al., 2016; Mustar and Wright, 2010). According to Miranda et al. (2017), the business environment significantly affects the PC of academics in the process of creating a company. Therefore, the following hypothesis is raised:

H9: ENV significantly influences the PC of academics.

\section{Methodology}

\section{Sample and data collection}

For the fulfillment of the purpose of this research, to analyze the incidence of motivational antecedents in the Academic Entrepreneurial Intention and the effect of individual factors and the context on that antecedents, an empirical study was carried out at the Universidad Autónoma de Sinaloa (UAS), located in northwestern Mexico, an educational institution that has considered in its Institutional Development Plan (2017-2021) the interest in generating technology-based companies through starting from the research results by academics and higher education students, to multiply the link and technology transfer.

The random sample was made up of university academics from various faculties of technical and social areas. It was surveyed in November 2019, distributed in person among academics, or thru an online format. Concentrating a total of 172 responses obtained. Table 1 summarizes the sociodemographic characteristics of the respondents. 
It should be noted that the sample size is appropriate for the study; it is above the specific requirements for the analysis using the modeling of structural equations for latent variables used in this research ${ }^{1}$.

Table 1. Demographic characteristics of the sample.

\begin{tabular}{|lrr|}
\hline $\mathbf{n}$ & $\mathbf{1 7 2}$ \\
Age & Min & 28 \\
Max & 67 \\
& Mean & 41.6 \\
& & 8.9 \\
Gender & Standard Deviation & \\
& Male & $108(62.8 \%)$ \\
Research & Female & $64(37.2 \%)$ \\
Experience & Yes & $96(55.8 \%)$ \\
& No & $76(44.2 \%)$ \\
& & \\
Knowledge & Physics-Mathematics & $21(12.2 \%)$ \\
Area & Biotechnology \& Agriculture & $52(30.2 \%)$ \\
& Chemistry-biology & $21(12.2 \%)$ \\
& Medicine & $7(4.1 \%)$ \\
& Engineering & $34(19.8 \%)$ \\
Social Science & $37(21.5 \%)$ \\
\hline
\end{tabular}

\section{Variables}

Previous studies related to entrepreneurial intention suggest the importance of considering how motivational, individual, and contextual factors influence intention formation (Antonieli et al., 2016; Knockaert et al., 2015). Thus, after analyzing contributions in the literature review to identify how the variables that comply with content validity have been measured, the scale of Miranda $e t$ al. (2017) was selected, which consists of 47 items obtained from previous studies.

The structure of items with the variables considered is as follow: Academic Entrepreneurial Intention (4), Attitude towards Entrepreneurship (4), Subjective Norm (4), Perceived Control (8), Creativity (5), Perceived Utility (5), Self-confidence (5), Business Experience (2),

\footnotetext{
${ }^{1}$ The minimum sample size should be the result of multiplying by 10 the maximum number of arrows pointing to a latent variable anywhere in the nomogram (Hair et al. 2016). Furthermore, the authors Hair et al. (2019) suggest that the sample size is determined from the use of the statistical program $\mathrm{G} *$ Power to carry out a statistical power analysis for different configurations of the model. Both requirements were fulfilled.
} 
Entrepreneurship Training (4) and Business Environment (6). The scale was measured on a 7-point Likert-type scale, which assesses the degree of agreement for each of the item statements: total disagrees (1) totally agree (7).

\section{Data analysis}

Data analysis was carried out using the multivariate Structural Equation Model technique, through the Partial Least Squares approach (PLS-SEM), mainly due to the following reasons:

1) It is oriented to the prediction of unobservable variables (latent variables)

2) The proposed theoretical model is complex

3) Large number of different latent variables, but with multiple or cross-dependence, can combine reflective and formative measures.

Therefore, the research model is analyzed and interpreted with the PLS-SEM approach, following Hair et al. (2019):

1) Evaluation of the measurement model, with reflective indicators, each item's individual reliability is analyzed, through factor loadings, scale reliability or internal consistency, convergent validity, and discriminant validity of the constructs.

2) Evaluation of the structural model to assess the direct effect of the exogenous latent variables on the endogenous latent variables. When evaluating the structural model, the relationships between the constructs are considered, estimating the parameters in a way that maximizes the explained variance of the latent or endogenous variables. The criteria to evaluate the structural model were as follows: the variance of the construct $\left(R^{2}\right)$ was obtained ${ }^{2}$, the predictive relevance of the model is validated through the Stone-Geisser Test $\left(Q^{2}\right)$, the percentage of explained variance is obtained as the product of the coefficient path and the correlation coefficient, and finally, the effect size $\left(\mathrm{f}^{2}\right)$ of each exogenous variable in the endogenous construct is measured.

Subsequently, bootstrapping (5000 subsamples) is used to generate t statistics and confidence intervals, which evaluates the statistical importance of the direct effects of the structural model that allows determining the non-rejection of the hypotheses raised.

The model was estimated using SmartPLS 3.0 software (Ringer et al., 2015). For the significance of the parameters, a value of $\mathrm{p}<0.05$ was considered, as it is the value that most researchers choose (Hair et al., 2016).

\footnotetext{
${ }^{2}$ Adjusted $\mathrm{R}^{2}$ is considered as a criterion to avoid bias in the research model (Hair et al., 2019).
} 


\section{$\underline{\text { Results }}$}

\section{Measurement model}

The evaluation of the measurement model for reliability and validity for reflective indicators, considered the individual reliability adequate because all the indicators had loads greater than 0.706, with the exception of nine items that were subsequently excluded (see Table 2 for the final list). Cronbach's Alpha for each construct lay between 0.696 and 0.907, indicative of good reliability and all the constructs comply with the composite reliability greater than 0.70 . To assess convergent validity, the average variance extracted (AVE) was examined; all latent variables reach a value higher than 0.50 .

Table 2. Measurement model evaluation.

\begin{tabular}{|c|c|c|c|c|}
\hline Construct/ítem & Loadings & $\begin{array}{l}\text { Cronbach's } \\
\text { Alpha }\end{array}$ & $\begin{array}{l}\text { Composite } \\
\text { Realiability }\end{array}$ & AVE \\
\hline Academic Entrepreneurial Intention (AEI) & & 0.772 & 0.867 & 0.686 \\
\hline I am determined to create a business in the future & 0.885 & & & \\
\hline I intend to commercialize the results of my research a spin-off & 0.822 & & & \\
\hline I would very much like to be an entrepreneur & 0.773 & & & \\
\hline Attitude toward Entrepreneurship (AE) & & 0.841 & 0.894 & 0.68 \\
\hline I find the idea of being an entrepreneur attractive & 0.853 & & & \\
\hline $\begin{array}{l}\text { Given the opportunity and resources, I would like to create a spin- } \\
\text { off business }\end{array}$ & 0.888 & & & \\
\hline $\begin{array}{l}\text { Being an entrepreneur would generate in me a feeling of great } \\
\text { satisfaction }\end{array}$ & 0.825 & & & \\
\hline I think if I decide to start a spin-off business then it would succeed & 0.724 & & & \\
\hline Subjetive Norm (SN) & & 0.798 & 0.868 & 0.622 \\
\hline My family would support me in my career as an entrepreneur & 0.739 & & & \\
\hline My friends see entrepreneurship as a logical option & 0.832 & & & \\
\hline The culture of my region encourages entrepreneurship & 0.791 & & & \\
\hline Most people in my region see entrepreneurship as very positive & 0.789 & & & \\
\hline Perceived Control (PC) & & 0.907 & 0.926 & 0.642 \\
\hline Recognize a business opportunity before others do & 0.752 & & & \\
\hline Make improvements to certain existing products on the market & 0.782 & & & \\
\hline Conduct market research for a new product & 0.793 & & & \\
\hline Design a marketing campaign for my products & 0.818 & & & \\
\hline Organize and maintain my business's financial information & 0.794 & & & \\
\hline Manage relationships with my employees & 0.847 & & & \\
\hline Develop a strategic plan & 0.818 & & & \\
\hline Creativity (CREA) & & 0.739 & 0.879 & 0.784 \\
\hline I consider myself a very creative person & 0.828 & & & \\
\hline I like to start new projects, despite the risk of being wrong & 0.940 & & & \\
\hline
\end{tabular}




\begin{tabular}{|c|c|c|c|c|}
\hline Perceived Utility (PU) & & 0.753 & 0.857 & 0.667 \\
\hline Being an entrepreneur would entail a very high degree of autonomy & 0.787 & & & \\
\hline $\begin{array}{l}\text { The personal satisfaction from being an entrepreneur would be very } \\
\text { high }\end{array}$ & 0.881 & & & \\
\hline $\begin{array}{l}\text { The quality of life that I would get from being an entrepreneur } \\
\text { would be very high }\end{array}$ & 0.779 & & & \\
\hline Self-confidence (SELF) & & 0.753 & 0.858 & 0.669 \\
\hline $\begin{array}{l}\text { Whether or not a target is reached depends mainly on me and my } \\
\text { behavior }\end{array}$ & 0.759 & & & \\
\hline When I make plans, I am sure that they will come to fruition & 0.853 & & & \\
\hline $\begin{array}{l}\text { Achieving what I want is the result of my own effort and personal } \\
\text { commitment }\end{array}$ & 0.839 & & & \\
\hline Business Experience (BE) & & 0.696 & 0.831 & 0.712 \\
\hline I have work experience in the private sector & 0.860 & & & \\
\hline I have experience as proprietor of another firm or other firms & 0.826 & & & \\
\hline Entrepreneurship Training (ET) & & 0.867 & 0.908 & 0.712 \\
\hline $\begin{array}{l}\text { The hours of training in entrepreneurship I received during my } \\
\text { university studies were adequate }\end{array}$ & 0.823 & & & \\
\hline $\begin{array}{l}\text { The hours of training in entrepreneurship I have received as part of } \\
\text { my university's teaching and research staff training programs have } \\
\text { been sufficient }\end{array}$ & 0.902 & & & \\
\hline $\begin{array}{l}\text { The hours of training in entrepreneurship I have received outside } \\
\text { the university have been sufficient }\end{array}$ & 0.825 & & & \\
\hline $\begin{array}{l}\text { My university gives good training to its teaching and research staff } \\
\text { for them to develop their entrepreneurial potential }\end{array}$ & 0.822 & & & \\
\hline Business Environment (ENV) & & 0.862 & 0.895 & 0.588 \\
\hline It is easy to obtain a bank loan to start a business & 0.706 & & & \\
\hline It is easy to find investors for a new business & 0.757 & & & \\
\hline There are enough grants and subsidies to create businesses & 0.811 & & & \\
\hline $\begin{array}{l}\text { There are sufficient consulting firms that can help start up a } \\
\text { business }\end{array}$ & 0.810 & & & \\
\hline $\begin{array}{l}\text { The country's economic situation will improve notably in the } \\
\text { coming years }\end{array}$ & 0.769 & & & \\
\hline $\begin{array}{l}\text { The conditions for entrepreneurs will improve notably in the } \\
\text { coming years }\end{array}$ & 0.745 & & & \\
\hline
\end{tabular}

In regard to discriminant validity, allows us to assess that each latent variable is different from other constructs in the model. According to the Fornell-Larcker criterion, each construct's diagonal indices is the square root of the average variance extracted (AVE) and must be the highest in any column or row (Table 3). In addition, in Table 4, heterotrait-monotrait (HTMT) ratio was considered, to estimate whether the monotrait-heteromethod correlations (correlations between the indicators that measure the same construct) are greater than the heterotrait-heteromethod (correlations between the indicators that measure different constructs), there will be discriminant validity. Thus, the HTMT ratio is considered conservative at a value of 0.85 , while values higher than 0.90 suggest lack of discriminant validity (Hair et al., 2019). In this case, there is only one 
value close to this critical point, HTMT in AEI-AE $=0.900$, this is due to the high correlation between the two variables.

Table 3. Discriminant Validity. Fornell-Larcker criterion.

\begin{tabular}{|c|c|c|c|c|c|c|c|c|c|c|c|c|}
\hline Variables & Mean & StDev & $\mathbf{A E}$ & SELF & ET & PC & CREA & $\mathrm{BE}$ & ENV & AEI & SN & PU \\
\hline $\mathbf{A E}$ & 5.412 & 1.076 & 0.825 & & & & & & & & & \\
\hline SELF & 5.742 & 0.938 & $0.376^{*}$ & 0.818 & & & & & & & & \\
\hline ET & 3.225 & 1.444 & $0.189 *$ & $0.158 *$ & 0.844 & & & & & & & \\
\hline PC & 4.861 & 1.170 & $0.523^{*}$ & $0.321 *$ & $0.367 *$ & 0.801 & & & & & & \\
\hline CREA & 5.845 & 0.892 & $0.464 *$ & $0.308 *$ & $0.221 *$ & $0.435^{*}$ & 0.886 & & & & & \\
\hline BE & 3.480 & 1.808 & $0.455^{*}$ & 0.129 & $0.266^{*}$ & $0.368^{*}$ & $0.203^{*}$ & 0.844 & & & & \\
\hline ENV & 3.807 & 1.109 & 0.089 & 0.098 & $0.352 *$ & $0.265^{*}$ & 0.134 & $0.231 *$ & 0.767 & & & \\
\hline AEI & 4.698 & 1.411 & $0.734 *$ & $0.272 *$ & $0.274 *$ & $0.563^{*}$ & $0.411 *$ & $0.378 *$ & $0.229^{*}$ & 0.828 & & \\
\hline SN & 5.180 & 1.083 & $0.385^{*}$ & $0.298 *$ & $0.412 *$ & $0.455^{*}$ & $0.351 *$ & $0.312 *$ & $0.317 *$ & 0.341 & 0.789 & \\
\hline PU & 5.420 & 0.973 & $0.659 *$ & $0.391 *$ & 0.122 & $0.322 *$ & $0.233^{*}$ & $0.375^{*}$ & 0.105 & $0.480 *$ & $0.479 *$ & 0.817 \\
\hline
\end{tabular}

Table 4. Discriminant Validity. Heterotrait-Monotrait ratio (HTMT).

AE SELF ET PC CREA BE ENV AEI SN PU

\begin{tabular}{lccccccccccc}
\hline AE & --- & & & & & & & & \\
SELF & 0.472 & & & & & & & & \\
ET & 0.219 & 0.218 & & & & & & & \\
PC & 0.594 & 0.377 & 0.396 & & & & & & \\
CREA & 0.57 & 0.411 & 0.286 & 0.529 & & & & & \\
BE & 0.640 & 0.265 & 0.359 & 0.495 & 0.303 & & & & \\
ENV & 0.113 & 0.167 & 0.407 & 0.285 & 0.178 & 0.307 & & & \\
AEI & 0.900 & 0.342 & 0.31 & 0.643 & 0.534 & 0.531 & 0.273 & & \\
SN & 0.471 & 0.373 & 0.501 & 0.523 & 0.475 & 0.453 & 0.388 & 0.414 & \\
PU & 0.809 & 0.531 & 0.173 & 0.379 & 0.292 & 0.546 & 0.145 & 0.609 & 0.637 \\
\hline
\end{tabular}

\section{Structural model}

Fig. 2 and Table 5 show the results of the evaluation of the structural model. In general, ranges of values obtained from adjusted $\mathrm{R}^{2}\left(0\right.$ to 1 ) and $\mathrm{Q}^{2}$ (greater than 0 ) indicate a high predictive precision of the model proposed in this research. The variance of the Academic Entrepreneurial Intention construct explained by this model is $57.6 \%$, of which PC contributes $13.96 \%$, SN is not significant, and $\mathrm{AE}$ is the construct that most contributes to explaining the AEI with $44.61 \%$. For the $\mathrm{AE}$ construct, the value of $\mathrm{R}^{2}$ is $56.2 \%$, mainly described by PU with $33.21 \%$, CREA contributes $13.83 \%$, and BE contributes $9.46 \%$. SELF and SN do not contribute to the variance of AE. 
Regarding PC, the value of the variance is $27.5 \%$, explained in a more significant proportion by SN with $13.65 \%$, BE with $8 \%$, ET with $6.10 \%$, and ENV not significant.

In particular, the bootstrap technique shows that 7 of the 12 direct effects on endogenous o independent variables are significant. Thus, $\mathrm{AE}(\beta=0.607 ; \mathrm{t}=10.03 ; \mathrm{p}<0.05)$ and $\mathrm{PC}(\beta=0.248$; $\mathrm{t}=3.329 ; \mathrm{p}<0.05)$ positively and significantly influence the AEI, otherwise the SN, which only shows a positive relationship and significant in the PC $(\beta=0.30 ; t=3.683 ; p>0.05)$.It should be noted that the values obtained from $\mathrm{f}^{2}$ allow us to ratify that $\mathrm{AE}$ emerges as the most important antecedent in AEI; it has a strong and significant effect, whereas PC is significant, but with a small effect on intention and SN does not have a direct effect on the AEI.

Regarding the direct relationships of the individual factors that precede the AE construct, only PU $(\beta=0.504 ; \mathrm{t}=7.434 ; \mathrm{p}<0.05)$, CREA $(\beta=0.298 ; \mathrm{t}=4.503 ; \mathrm{p}<0.05)$ and $\mathrm{BE}(\beta=0.208$; $\mathrm{t}=3.436 ; \mathrm{p}<0.05)$ are the significant variables with large, moderate, and small direct effect, respectively. In reference, to the contextual factors that precede the PC construct, $\mathrm{BE}(\beta=0.217 ; \mathrm{t}$ $=2.803 ; \mathrm{p}<0.05)$ and $\mathrm{ET}(\beta=0.165 ; \mathrm{t}=2.415 ; \mathrm{p}<0.05)$ are significant, but with a small effect.

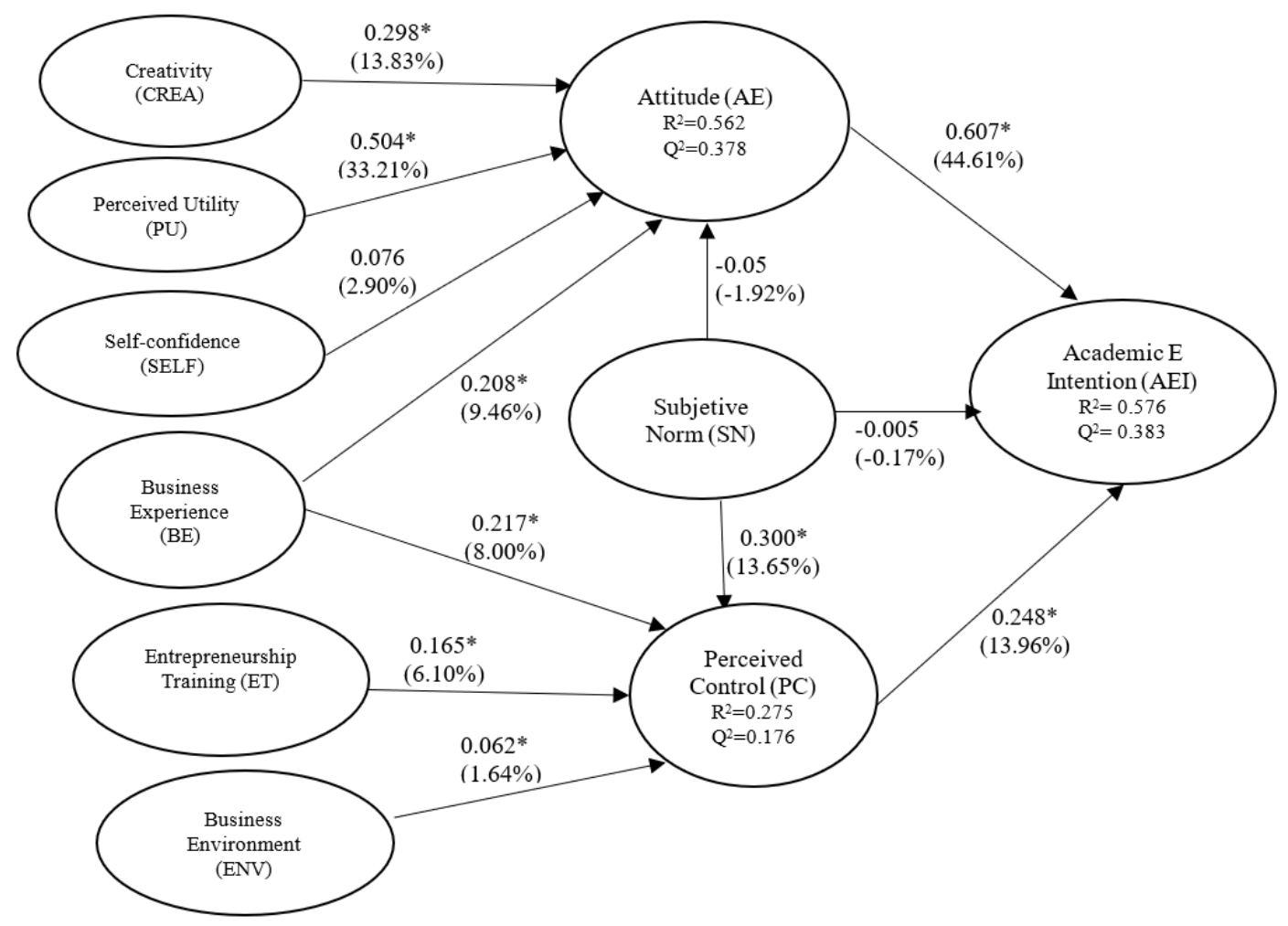

Fig. 2. Results of the structural model.

The values, in the arrows, indicate the beta coefficients and, in parentheses, the explained variance

* Denotes a significant direct effect at $\mathrm{p}<0.05$. 
Table 5. Result of the Structure Model.

\begin{tabular}{|c|c|c|c|c|c|}
\hline Hypothesis & $\begin{array}{c}\text { Direct } \\
\text { Effect } \beta\end{array}$ & t-Value & P Value & $\begin{array}{l}\text { Explained } \\
\text { Variance }\end{array}$ & $f^{2}$ \\
\hline $\mathrm{H} 1: \mathrm{AE} \rightarrow \mathrm{AEI}$ & 0.607 & 10.03 & 0.000 & $44.61 \%$ & 0.619 \\
\hline $\mathrm{H} 2: \mathrm{SN} \rightarrow \mathrm{AEI}$ & -0.005 & 0.092 & 0.927 & $-0.17 \%$ & 0.000 \\
\hline $\mathrm{H} 2 \mathrm{a}: \mathrm{SN} \rightarrow \mathrm{AE}$ & -0.05 & 0.832 & 0.405 & $-1.92 \%$ & 0.004 \\
\hline $\mathrm{H} 2 \mathrm{~b}: \mathrm{SN} \rightarrow \mathrm{PC}$ & 0.300 & 3.683 & 0.000 & $13.65 \%$ & 0.097 \\
\hline $\mathrm{H} 3: \mathrm{PC} \rightarrow \mathrm{AEI}$ & 0.248 & 3.329 & 0.001 & $13.96 \%$ & 0.096 \\
\hline $\mathrm{H} 4: \mathrm{CREA} \rightarrow \mathrm{AE}$ & 0.298 & 4.503 & 0.000 & $13.83 \%$ & 0.172 \\
\hline H5: PU $\rightarrow$ AE & 0.504 & 7.434 & 0.000 & $33.21 \%$ & 0.388 \\
\hline H6: SELF $\rightarrow$ AE & 0.076 & 1.29 & 0.197 & $2.90 \%$ & 0.011 \\
\hline $\mathrm{H} 7 \mathrm{a}: \mathrm{BE} \rightarrow \mathrm{AE}$ & 0.208 & 3.436 & 0.001 & $9.46 \%$ & 0.084 \\
\hline $\mathrm{H} 7 \mathrm{~b}: \mathrm{BE} \rightarrow \mathrm{PC}$ & 0.217 & 2.803 & 0.005 & $8.00 \%$ & 0.058 \\
\hline H8: ET $\rightarrow$ PC & 0.165 & 2.415 & 0.016 & $6.10 \%$ & 0.029 \\
\hline H9:ENV $\rightarrow$ PC & 0.062 & 0.887 & 0.375 & $1.64 \%$ & 0.004 \\
\hline
\end{tabular}

\section{$\underline{\text { Discussion }}$}

The structural model of the research shows a 57.6\% explanation of the variance of AEI. This percentage is higher than those obtained by previous studies academic entrepreneurship between 35 and 50\% (Alonso-Galicia et al., 2015; Feola et al., 2017; Fernández-Pérez et al., 2014).

Regarding the motivational factors (AE, SN, and PC) that directly precede the AEI, the results obtained show that the $\mathrm{AE}$ presents a positive and significant relationship with a greater influence on the intention to become an entrepreneur. On the other hand, PC has a significant impact, but with a small effect. However, SN does not significantly affect AEI or AE; it only significantly affects PC. This agrees with previous research supports that in non-business environments such as universities, it is the characteristics of the academic, his positive attitude towards generating spin-off companies, has a more significant influence on intention, in contrast to formal factors such as institutional or organizational support measures (Guerrero et al., 2016; Miranda et al., 2017; Urban and Chantson, 2017).

However, regarding AE's dominant influence as an antecedent of intention, the present study's findings reveal a significant but weak relationship between PC in AEI. This contrasts with previous research, in which they find the PC not significant (Miranda et al., 2017; Piperopoulos and Dimov, 2015) and with those that find that the PC is the main determinant of intentions, where AE and SN act as support (Feola et al., 2017). An explanation for this result could be found in the characteristics of the sample of academic researchers, who consider that with the more significant 
human capital, they could develop the skills and abilities necessary to start a business when the time comes. The PC will be more influential when initiating entrepreneurial behavior and not when the business intention is formed (Kautonen et al., 2015).

Regarding the SN, that is, the perception by family, friends, and co-workers that the academic decides to become an entrepreneur, the results show that it does not directly influence the AEI, only indirectly with a small effect through the PC. This finding agrees with previous studies that support that SN tends to vary according to culture or environment (Liñan et al., 2011), in Latin America and the Anglo-Saxon region, both the success or failure of business activities are viewed and judged from differently, for example, when the academic knows a colleague who has started a spin-off and has a positive experience, it will positively influence the SN and PC; otherwise, if they have had an experience of failure to become an entrepreneur, it may not negatively affect any antecedent of the intention but be significant because the individual considers that the experience, even when it was negative, has served to acquire knowledge (Passaro et al., 2017; Sieger and Monsen, 2015).

Concerning the individual factors that precede AE, they are CREA, PU, and BE, which positively and significantly affect the academic attitude towards entrepreneurship. This is in line with the results obtained with Miranda et al. (2017), who argue that, in the academic field, it is necessary to encourage entrepreneurial activities as a mechanism to transfer technology and, to be considered together with teaching and research, with the same recognition by the educational institution.

On the other hand, the contextual factors that precede the $\mathrm{PC}$ are $\mathrm{BE}$ and $\mathrm{ET}$, presenting a positive and significant direct effect. According to the theory, it sustains that the academic who has experience in the business sector, whether due to having developed a spin-off or for research reasons, had a link with the industry, will have a PC to carry out entrepreneurial activities. Besides, together with entrepreneurship training for academics and students, it will allow the development of skills that favor university spin-offs. (Bienkowska et al., 2016; Perkman et al., 2013; Rasmussen and Wright, 2015).

\section{Conclusions}

Starting from the Theory of Planned Behavior (TPB), the present study had as objectives: to analyze the incidence of motivational antecedents (attitude, subjective norm, and perceived 
Control) on Academic Entrepreneurial Intention and to examine the effect of individual factors and context in the background of the AEI; with the idea of contributing to the open gaps of investigating the determinants of the intention to create an academic spin-off.

Thus, our research's empirical sample was made up of academics from the Universidad Autónoma de Sinaloa, a public institution that shows interest in creating science-based companies. The results obtained provide predictive evidence of unobservable variables that influence the formation of intention in the academic environment.

Based on the methodology used, PLS-SEM, the following results were obtained:

1) With respect to motivational antecedents in the intention, our analysis showed that the Attitude towards Entrepreneurship is the variable with the most significant influence on the formation of the Academic Entrepreneurial Intention.

2) In regard to the individual factors with the most significant effect on Attitude are the Perceived Utility by the academic, the perception of economic benefit, amount of anticipated work effort, among others, to achieve utility are essential factors when deciding to become an entrepreneur.

3) Likewise, the Creativity and the Business Experience of the academic, with a moderate and small effect, respectively, affect the attitude towards entrepreneurship.

This research contains academic implications, the proposed theoretical model allows in general, contributing to the study of Entrepreneurial Intentions and, in particular, intentions among university academics. The incorporation of new theoretical perspectives to the study of entrepreneurial intention allows to continue with the individual analysis with different approaches; for example, integrating the cognitive aspects of the TPB and the elements of the Triple Helix (government, industry, academia) can contribute to the sustenance of the determinants of the formation of the AEI. In the same way, considering theoretical approaches proven in organizational studies, such as the resource-based approach to the company or the theory of social networks, can provide excellent foundations to understand how to encourage entrepreneurial intention in the academic environment.

Regarding the practical implications of the study, due to the importance of the transfer of university technology to generate competitive advantage, economic and social development in the region, and considering the relevant role of the individual in the entrepreneurial process, it is useful 
that the university authorities know the factors that allow promoting entrepreneurship activities, in particular, the creation of academic spin-offs.

In this sense, some university environment agents' support is essential, such as technology transfer offices, science, and technology parks, in the training of academics to develop their creativity and identify business opportunities in the research results, which can favor the attitude and perceived control towards entrepreneurship.

In the same direction, the empirical results show the need to promote a university culture that favors academic entrepreneurship, providing support through tangible and intangible resources. Specifically, the findings indicate that utility perceived by the academics of Universidad Autónoma de Sinaloa is a significant factor in having a positive attitude towards entrepreneurship; therefore, the university must establish specific regulations for innovation, linkage, and entrepreneurship; for example, prevention and treatment of conflict of interest between the academic and the institution, regarding the participation of royalties and incentives when participating in entrepreneurial activities, particularly in creating spin-offs.

Our study has some limitations that suggest gaps for future lines of research. Only the direct effects between the individual, contextual and motivational factors that precede the IEA have been analyzed; future studies towards identifying new relationships between the determining factors and the intention may consider the moderating effect of the academic's personal and professional characteristics. Besides, carry out a longitudinal study that allows analyzing factors that affect the link or "bridge" from entrepreneurial intention to the subsequent entrepreneurial behavior. Finally, considering results obtained can only be generalized to the sample studied, it is convenient to extend the study with a more significant number of universities that allow comparisons in different university settings, considering institutions that already have success stories in academic spin-offs with null or low academic entrepreneurship.

\section{References}

Ajzen, I. (1991). The theory of planned behavior. Organizational Behavior and Human Decision Processes, 50(1), 179-211. DOI: https://doi.org/10.1016/0749-5978(91)90020-T

Ajzen, I. (2002). Perceived behavioral control, self-efficacy, locus of control, and the theory of planned behavior. Journal of applied social psychology, 32(4), 665-683. DOI: https://doi.org/10.1111/j.1559-1816.2002.tb00236.x 
Ajzen, I. (2011). Theory of planned behavior: reactions and reflections. Psychology \& Health, 26(9), 1113-1127. DOI: https://doi.org/10.1080/08870446.2011.613995

Ajzen, I. \& Fishbein, M. (1980). Understanding attitudes and predicting social behavior. Englewood Cliffs: Prentice-Hall.

Al-Jubari, I., Hassan, A., \& Liñan, F. (2018). Entrepreneurial intention among university students in Malaysia: integrating self-determination theory and the theory of planned behavior. International Entrepreneurship Management Journal, 15(4), 1323-1342. DOI: https://doi.org/10.1007/s11365-018-0529-0

Al-Mamary, Y. H. S., Abdulrab, M., Alwaheeb, M. A., \& Alshammari, N. G. M. (2020). Factors impacting entrepreneurial intentions among university students in Saudi Arabia: testing an integrated model of TPB and EO. Education+Training, 62(7/8), 779-803. DOI: https://doi.org/10.1108/ET-04-2020-0096

Alonso-Galicia, P. E., Fernández-Pérez, V., Rodríguez-Ariza, L., \& del Mar Fuentes-Fuentes, M. (2015). Entrepreneurial cognitions in academia: exploring gender differences. Journal of Managerial Psychology, 30(6), 630-644. DOI: https://doi.org/10.1108/JMP-08-2013-0262

Antonieli, D., Nicolli, F., Ramaciotti, L. \& Rizzo, U. (2016). The effect of intrinsic and extrinsic motivations on academics' entrepreneurial intention. Administrative Science, 6(15), 2-18. DOI: https://doi.org/10.3390/admsci6040015

Batool, H., Rasheed, H., Malik, M.I. \& Hussain, S. (2015). Application of partial least square in predicting e-entrepreneurial intention among business students: evidence from Pakistan. Journal of Innovation and Entrepreneurship, 4(1), 6. DOI: https://doi.org/10.1186/s13731$\underline{015-0019-3}$

Bienkowska, D., Klofsten, M., \& Rasmussen, E. (2016). PhD students in the entrepreneurial university-perceived support for academic entrepreneurship. European Journal of Education, 51(1), 56-72. DOI: https://doi.org/10.1111/ejed.12160

Bird, B. (1988). Implementing entrepreneurial ideas: The case for intention. Academy of Management Review, 13(3), 442-453. DOI: https://doi.org/10.5465/amr.1988.4306970

Carsrud, A., \& Brannback, M. (2011). Entrepreneurial motivations: What do we still need to know? Journal of Small Business Management, 49(1), 9-26. DOI: https://doi.org/10.1111/j.1540$\underline{627 X .2010 .00312 . X}$ 
Davey, T., Rossano, S., \& van der Sijde, P. (2016). Does context matter in academic entrepreneurship? The role of barriers and drivers in the regional and national context. Journal of Technology Transfer, 41(6), 1457-1458. DOI: https://doi.org/10.1007/s10961$\underline{015-9450-7}$

Deprez, J., Cools, E., Robijn, W., \& Euwema, M. (2019). Choice for an Entrepreneurial Career: Do Cognitive Styles Matter? Entrepreneurship Research Journal, 0(0). DOI: https://doi.org/10.1515/erj-2019-0003

D’Este, P., \& Perkmann, M., (2011). Why do academics engage with industry? The entrepreneurial university and individual motivations. The Journal of Technology Transfer 36, 316-339. DOI: https://doi.org/10.1016/j.respol.2012.09.007

Entrialgo, M., \& Iglesias, V. (2016). The moderating role of entrepreneurship education on the antecedents of entrepreneurial intention. International Entrepreneurship and Management Journal, 12(4), 1209-1232. DOI: https://doi.org/10.1007/s11365-016-0389-4

Erikson, T., Knockaert, M., \& Der Foo, M. (2015). Enterprising scientists: The shaping role of norms, experience, and scientific productivity. Technological Forecasting and Social Change, 99, 211-221. DOI: https://doi.org/10.1016/j.techfore.2015.06.022

Etzkowitz, H., Webster, A., Gebhardt, C. \& Cantisano, B. (2000). The future of the university and the university of the future: evolution of ivory tower to entrepreneurial paradigm. Research Policy, 29, 313-330. DOI: https://doi.org/10.1016/S0048-7333(99)00069-4

Feola, R., Vesci, M., Botti, A., \& Parente, R. (2017): The determinants of entrepreneurial intention of young researchers: combining the theory of planned behavior with the triple helix model. Journal of Small Business Management, 57(4), 1424-1443. DOI: https://doi.org/10.1111/jsbm.12361

Fernández-Pérez, V., Esther Alonso-Galicia, P., del Mar Fuentes-Fuentes, M., \& Rodríguez-Ariza, L. (2014). Business social networks and academics 'entrepreneurial intentions. Industrial Management \& Data Systems, 114(2), 292-320. DOI: https://doi.org/10.1108/IMDS-02$\underline{2013-0076}$

Fernández-Pérez, V., Alonso-Galicia, P. E., Rodríguez-Ariza, L., \& del Mar Fuentes-Fuentes, M. (2015). Professional and personal social networks: A bridge to entrepreneurship for academics? European Management Journal, 33(1), 37-47. DOI: https://doi.org/10.1016/j.emj.2014.07.003 
Ferreira, J. J., Raposo, M. L., Rodrigues, R. G., Dinis, A., \& do Pac, o, A. (2012). A model of entrepreneurial Intention: An application of the psychological and behavioral approaches. Journal of Small Business and Enterprise Development, 19(3), 424-440. DOI: https://doi.org/10.1108/14626001211250144

Fini, R., Grimaldi, R., Marzocchi, G. L., \& Sobrero, M. (2012). The determinants of corporate entrepreneurial intention within small and newly established firms. Entrepreneurship Theory and Practice, 36(2), 387-414. DOI: https://doi.org/10.1111/j.1540$\underline{6520.2010 .00411 . x}$

Fini, R., \& Toschi, L. (2015). Academic logic and corporate entrepreneurial intentions: a study of the interaction between cognitive and institutional factors in new firms. International Small Business Journal, 34(5), 637-659. DOI: https://doi.org/10.1177/0266242615575760

Foo, M. D., Knockaert, M., Chan, E. T., \& Erikson, T. (2016). The individual environment nexus: Impact of promotion focus and the environment on academic scientists 'entrepreneurial intentions. IEEE Transactions on Engineering Management, 63(2), 213-222. DOI: https://doi.org/10.1109/TEM.2016.2535296

Goel, R. K., Goktepe-Hulten, D., \& Ram, R. (2015). Academics' entrepreneurship propensities and gender differences. Journal of Technology Transfer, 40(1), 161-177. DOI: https://doi.org/10.1007/s10961-014-9372-9

Goethner M, Obschonka M, Silbereisen R. et al. (2012) Scientists' transition to academic entrepreneurship: Economic and psychological determinants. Journal of Economic Psychology 33(3): 628-641. DOI: https://doi.org/10.1016/j.joep.2011.12.002

Guerrero, M. \& Urbano, D. (2014). Academics' start-up intentions and knowledge filters: an individual perspective of the knowledge spillover theory of entrepreneurship. Small Business Economics, 43, 57-74. DOI: https://doi.org/10.1007/s11187-013-9526-4

Guerrero, M., Urbano, D., Fayolle, A., Klofsten, M. \& Mian, S. (2016) Entrepreneurial universities: emerging models in the new social and economic landscape. Small Business Economics 47(3): 551-563. DOI: https://doi.org/10.1007/s11187-013-9526-4

Hair, J. F., Jr., Hult, G. T. M., Ringle, C., \& Sarstedt, M. (2016). A primer on partial least squares structural equation modeling (PLS-SEM). Thousand Oaks, California: Sage publications. 
Hair, J. F., Risher, J. J., Sarstedt, M. \& Ringle, C. M. (2019). When to use and how to report the results of PLS-SEM. European Business Review 31(1), 2-24. DOI: https://doi.org/10.1108/EBR-11-2018-0203

Hu, R., Wang, L., Zhang, W., \& Bin, P. (2018). Creativity, proactive personality, and entrepreneurial intention: the role of entrepreneurial alertness. Frontiers in psychology, 9, 951. DOI: https://doi.org/10.3389/fpsyg.2018.00951

Huyghe, A., \& Knockaert, M. (2015). The influence of organizational culture and climate on entrepreneurial intentions among research scientists. The Journal of Technology Transfer, 40(1), 138-160. DOI: https://doi.org/10.1007/s10961-014-9333-3

Jain, S., George, G. \& Maltarich, M. (2009). Academics or entrepreneurs? Investigating role identity modification of university scientists involved in commercialization activity. Research Policy, 38(6), 922-935. DOI: https://doi.org/10.1016/j.respol.2009.02.007

Kautonen, T., van Gelderen, M., \& Fink, M. (2015). Robustness of the theory of planned behavior in predicting EI and actions. Entrepreneurship Theory and Practice, 39(3), 655-674. DOI: https://doi.org/10.1111/etap.12056

Kautonen, T., van Gelderen, M., \& Tornikoski, E. T. (2013). Predicting entrepreneurial behavior: A test of the theory of planned behavior. Applied Economics, 45(6), 697-707. DOI: https://doi.org/10.1080/00036846.2011.610750

Knockaert, M., Foo, M., Erikson, T. \& Cools, E. (2015). Growth intentions among research scientists: a cognitive style perspective. Technovation, 38: 64-74. DOI: https://doi.org/10.1016/j.technovation.2014.12.001

Kolvereid, L. (2016). Preference for self-employment prediction of new business start-up intentions and efforts. The International Journal of Entrepreneurship and Innovation, 17(2), 100-109. DOI: https://doi.org/10.1177/1465750316648576

Krueger, N. \& Brazeal, D. (1994). Entrepreneurial potential and potential entrepreneurs. Entrepreneurship and Regional Development, 5(1), 315-330. DOI: https://doi.org/10.1177/104225879401800307

Krueger, N., Reilly, M. \& Carsrud, A. (2000). Competing models of entrepreneurial intentions. Journal of Business Venturing, 15(5), 411-432. DOI: https://doi.org/10.1016/S0883$\underline{9026(98) 00033-0}$ 
Liñán, F. \& Chen, Y. (2009). Development and Cross-Cultural Application of a Specific Instrument to Measure Entrepreneurial Intentions. Entrepreneurship: Theory and Practice 33(3), 593617. DOI: https://doi.org/10.1111/j.1540-6520.2009.00318.x

Liñan, F. \& Fayolle, A. (2015). A systematic literature review on entrepreneurial intentions: citation, thematic analyses, and research agenda. International Entrepreneurship and Management Journal, 11(4), 907-933. DOI: https://doi.org/10.1007/s11365-015-0356-5

Liñán, F., Urbano, D., \& Guerrero, M. (2011). Regional variations in entrepreneurial cognitions: Start-up intentions of university students in Spain. Entrepreneurship \& Regional Development, 23(3-4), 187-215. DOI: https://doi.org/10.1080/08985620903233929

Lortie, J., \& Castogiovanni, G. (2015). The theory of planned behavior in entrepreneurship research: What we know and future directions. International Entrepreneurship and Management Journal, 11(4), 935-957. DOI: https://doi.org/10.1007/s11365-015-0358-3

Margahana, H. (2019). Self-Efficacy, Self-Personality And Self Confidence On Entrepreneurial Intention: Study On Young Enterprises. Journal of Entrepreneurship Education, 22(1), 112.

Miranda, F. J., Chamorro-Mera, A., \& Rubio, S. (2017). Academic entrepreneurship in Spanish universities: An analysis of the determinants of entrepreneurial intention. European research on management and business economics, 23(2), 113-122. https://doi.org/10.1016/j.iedeen.2017.01.001

Miranda, F., Chamorro, A. \& Rubio, S. (2018). Re-thinking university spin-off: A critical literature review and a research agenda. Journal of Technology Transfer, 43(4), 1007-1038. DOI: https://doi.org/10.1007/s10961-017-9647-Z

Moog, P., Werner A., Houweling S., \& Backes-Gellner, U. (2015). The impact of skills, working time allocation and peer effects on the entrepreneurial intentions of scientists. The Journal of Technology Transfer, 40, 493-511.

Mustar, P., \& Wright, M. (2010). Convergence or path dependency in policies to foster the creation of university spin-off firms? A comparison of France and the United Kingdom. The Journal of Technology Transfer, 35(1), 42-65. DOI: https://doi.org/10.1007/s10961-009-9113-7

Obschonka, M., Silbereisen, R. K., Cantner, U., \& Goethner, M. (2015). Entrepreneurial selfidentity: Predictors and effects within the theory of planned behavior framework. Journal 
of Business and Psychology, 30(4), 773-794. DOI: https://doi.org/10.1007/s10869-014$\underline{9385-2}$

Passaro, R., Scandurra, G. \& Thomas, A. (2017). The Emergence of Innovative Entrepreneurship: Beyond the Intention - Investigating the Participants in an Academic SUC. International Journal of Innovation and Technology Management, 14(5), 1750025 (22 pages). DOI: https://doi.org/10.1142/S0219877017500250

Perkmann, M., Tartari, V., McKelvey, M., Autio, E., Broström, A., D’Este, P. et al. (2013). Academic engagement and commercialization: A review of the literature on universityindustry relations. Research policy, 42(2), 423-442. DOI: https://doi.org/10.1016/j.respol.2012.09.007

Piperopoulos, P., \& Dimov, D. (2015). Burst bubbles or build steam? Entrepreneurship education, entrepreneurial self-efficacy, and entrepreneurial intentions. Journal of Small Business Management, 53(4), 970-985. DOI: https://doi.org/10.1111/jsbm.12116

Prodan, I. \& Drnovsek, M. (2010). Conceptualizing academic-entrepreneurial intentions: An empirical test. Technovation, 30(5), 332-347. DOI: https://doi.org/10.1016/j.technovation.2010.02.002

Rasmussen, E., Mosey, S., \& Wright, M. (2014). The influence of university departments on the evolution of entrepreneurial competencies in spin-off ventures. Research Policy, 43(1), 92106. DOI: https://doi.org/10.1016/j.respol.2013.06.007

Rasmussen, E. y Wright, M. (2015). How can universities facilitate academic spin-offs? An entrepreneurial competency perspective. Journal of Technology Transfer, 40(5), 782- -799. DOI: https://doi.org/10.1007/s10961-014-9386-3

Rauch, A., \& Hulsink, W. (2015). Putting entrepreneurship education where the intention to act lies: An investigation into the impact of entrepreneurship education on entrepreneurial behavior. Academy of Management Learning \& Education,14(2), 187-204. DOI: https://doi.org/10.5465/amle.2012.0293

Ringle, Christian M., Wende, Sven \& Becker, Jan-Michael. (2015). SmartPLS 3. Bönningstedt: SmartPLS. Retrieved from http://www.smartpls.com

Shahab, Y., Chengang, Y., Arbizu, A. D., \& Haider, M. J. (2018). Entrepreneurial self-efficacy and intention: do entrepreneurial creativity and education matter? International Journal of Entrepreneurial Behavior \& Research. DOI: https://doi.org/10.1108/ijebr-12-2017-0522 
Shapero, A., \& Sokol, L. (1982). Social Dimensions of Entrepreneurship. In C. Kent, D. Sexton and K. Vespers (Eds), The Encyclopedia of Entrepreneurship.: Prentice-Hall: Englewood Cliffs, NJ 72-90.

Shi, Y., Yuan, T., Bell, R., \& Wang, J. (2020). Investigating the Relationship Between Creativity and Entrepreneurial Intention: The Moderating Role of Creativity in the Theory of Planned Behavior. Frontiers in Psychology, 11. DOI: https://doi.org/10.3389/fpsyg.2020.01209

Sieger, P., \& Monsen, E. (2015). Founder, academic, or employee? A nuanced study of career choice intentions. Journal of Small Business Management, 53(S1), 30-57. DOI: https://doi.org/10.1111/jsbm.12181

Urban, B. \& Chantson, D. (2017). Academic entrepreneurship in South Africa: testing for entrepreneurial intentions. DOI: https://doi.org/10.1007/s10961-017-9639-Z

Van Gelderen, M., Brand, M., Van Praag, M., Bodewes, W., Poutsma, E., \& Van Gils, A. (2008). Explaining entrepreneurial intentions by means of the theory of planned behavior. Career Development International, 13(6), 538-559. DOI: https://doi.org/10.1108/13620430810901688

Wang, M., Cai, J., \& Munir, H. (2020). Academic entrepreneurship in China: individual human capital and institutional context in higher education organizations. Asian Journal of Technology Innovation, 1-24. DOI: https://doi.org/10.1080/19761597.2020.1833354

Wang, M., Soetanto, D., Cai, J., \& Munir, H. (2021). Scientist or Entrepreneur? Identity centrality, university entrepreneurial mission, and academic entrepreneurial intention. The Journal of Technology Transfer, 1-28. DOI: https://doi.org/10.1007/s10961-021-09845-6

Wright, M. (2014). Academic entrepreneurship, technology transfer and society: where next? Journal Technology Transfer, 39, 322-334. DOI: 10.1007/s10961-012-9286-3. DOI: https://doi.org/10.1007/s10961-012-9286-3

Wu, L., \& Li, J. (2011). Perceived value of entrepreneurship. Journal of Chinese Entrepreneurship, 3(2), 134-146. DOI: https://doi.org/10.1108/17561391111144564

Zampetakis, L. A., Kafetsios, K., Bouranta, N., Dewett, T., \& Moustakis, V. S. (2009). On the relationship between emotional intelligence and entrepreneurial attitudes and intentions. International Journal of Entrepreneurial Behavior \& Research, 15(6), 595-618. DOI: https://doi.org/10.1108/13552550910995452 
Zampetakis, L. A., Gotsi, M., Andriopoulos, C., \& Moustakis, V. (2011). Creativity and entrepreneurial intention in young people. Empirical insights from business school students. The International Journal of Entrepreneurship and Innovation,12(3), 189-199. DOI: https://doi.org/10.5367/ijei.2011.0037

Zhang, X., and Zhang, K. (2018). The relation between creativity and entrepreneurial intention: a moderated mediating effect model. Foreign Economics \& Management. 40, 67-78. DOI: https://doi.org/10.16538/j.cnki.fem.2018.03.005 